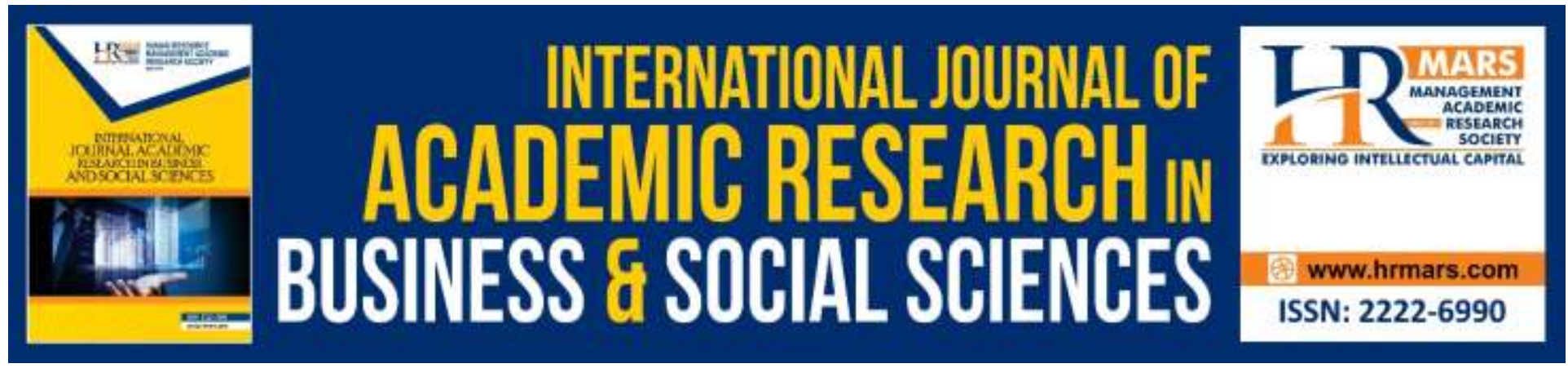

\title{
Positive Youth Development as an Indicator of the Effectiveness of Juvenile Rehabilitation Program
}

\author{
Hezzrin Mohd Pauzi
}

To Link this Article: http://dx.doi.org/10.6007/IJARBSS/v9-i7/6189

DOI: $10.6007 /$ IJARBSS/v9-i7/6189

Received: 12 May 2019, Revised: 23 June 2019, Accepted: 30 June 2019

Published Online: 29 July 2019

In-Text Citation: (Pauzi, 2019)

To Cite this Article: Pauzi, H. M. (2019). Positive Youth Development as an Indicator of the Effectiveness of Juvenile Rehabilitation Program. International Journal of Academic Research in Business and Social Sciences, 9(7), 909-914.

Copyright: (c) 2019 The Author(s)

Published by Human Resource Management Academic Research Society (www.hrmars.com)

This article is published under the Creative Commons Attribution (CC BY 4.0) license. Anyone may reproduce, distribute, translate and create derivative works of this article (for both commercial and non-commercial purposes), subject to full attribution to the original publication and authors. The full terms of this license may be seen

at: http://creativecommons.org/licences/by/4.0/legalcode

\section{Vol. 9, No. 7, 2019, Pg. 909 - 914}

http://hrmars.com/index.php/pages/detail/IJARBSS

JOURNAL HOMEPAGE

Full Terms \& Conditions of access and use can be found at http://hrmars.com/index.php/pages/detail/publication-ethics 


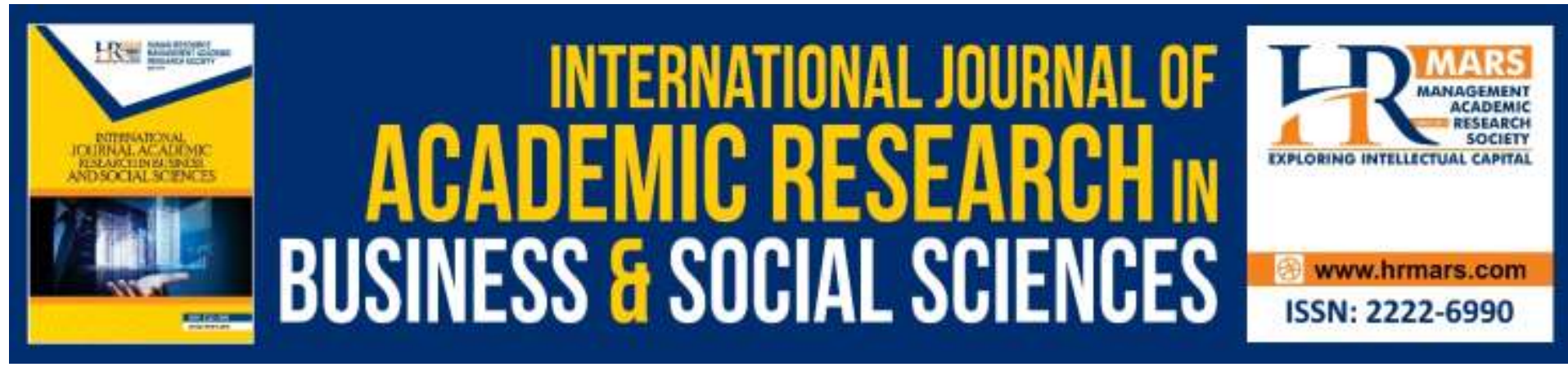

\title{
Positive Youth Development as an Indicator of the Effectiveness of Juvenile Rehabilitation Program
}

\author{
Hezzrin Mohd Pauzi \\ School of Social Work, Faculty of Applied Social Sciences, University Sultan Zainal Abidin, \\ Gong Badak Campus, 21300 Kuala Terengganu, Terengganu, Malaysia.
}

\begin{abstract}
Juvenile rehabilitation program is to reform their negative behavior. This rehabilitation includes aspects such as self-discipline development, virtue inculcation, skills development, education improvement and positive interaction development with people around them. All these aspects of positive youth development are indicators for the effectiveness of juvenile rehabilitation program. Thus, this article discusses the aspects of positive youth development that need to be achieved among the juvenile residents that undergo rehabilitation program. This study was done based on literature review through articles and books related to positive youth development and the effectiveness of rehabilitation program. This article is beneficial to rehabilitation field, social work and prison field in improving the effectiveness of rehabilitation program.
\end{abstract}

Keywords: Social Work, Positive Youth Development, the Effectiveness of Rehabilitation Program, Juvenile.

\section{Introduction}

Past studies have shown that indicator of recurrent criminal rate or recidivism is viewed as an indicator of the effectiveness of rehabilitation program (Cunneen \& Luke, 2007). However, this indicator is not easily measured as the main indicator of the effectiveness of reform program (Spiranovic et al., 2015). According to Barton and Butts (2008), the effectiveness of rehabilitation program could be measured through trainees' positive development, among others, from the aspects of cognitive, physical, education, skills and social relationship. Delgado (2002) has stated that positive youth development refers to children, teenagers or youth that focuses on youth asset such as strength, physical needs and social needs. Thus, the indicator of positive youth development is viewed as an essential indicator in measuring the achievement level of the implementation of rehabilitation program among juvenile trainee.

\section{Methodology}

The methodology used was based upon content analysis, that is the reading of journal articles, books, and theses related to the positive youth development, juvenile rehabilitation program and effectiveness program. These articles were searched for using several keywords through various internet search engines such as the Web of Sciences, SCOPUS, ERA and Google Scholar 
database. Terms such as "positive youth development", "effectiveness program", and "juvenile rehabilitation program" were used as keywords in finding information. To acquire even more detailed information regarding positive youth development and effectiveness of juvenile rehabilitation programs, literature review was also carried out.

\section{Study's Highlights}

\section{Positive Youth Development}

Generally, the focus on positive development process among youth functions as a foundation to develop positive element in self-potential (Lerner et al., 2005). Positive development is an effort to enhance optimal result through the implementation of youth's program (Lerner et al., 2013). According to Overton and Muller (2012), youth have the strength and unique asset that could be developed in building positive development. Meanwhile, according to Lerner et al. (2005), positive youth development concept consists of 5C elements: competence, confidence, character, connection and caring. Hamilton, Hamilton and Pittman (2004) in Barton and Butts (2008 have stated that among positive development principles that need to be attained are from the aspects of goals (all youth gain competence and character), practices (youth participation in decisions; good rapport with adults, peers and younger children; relationships changing and enduring as developmentally appropriate), and system characteristics (community-wide partnerships that develop inclusive, coherent, connected, and enduring systems).

\section{What is the Underlying theory of Positive youth Development?}

Positive youth development is one of the reform principle that needs to be acquired by rehabilitation centers. It is based on Strengths Perspective by Saleebey (1992). This perspective is one of the theory in social work practice to empower juvenile offenders (Saleebey, 1992). Prior to the usage of this strengths perspective, several approaches were very similar to it: development resilience, healing and wellness, solution focused therapy and asset-based community development (Saleebey, 2006). This perspective emphasizes early assessment on the strength of each client and not on the problem or weakness of that individual. Identified clients' personal strengths or abilities are enhanced further to overcome their problem (Saleebey, 1992). This means, this perspective views that every individual has power source and potential to develop part of their live that is not yet utilized. Thus, any intervention or treatment that applies this strengths principle is empowering clients' strengths, which are evaluated by social workers, and is not to overcome clients' problems.

There is growing interest in strengths-based positive youth development concepts as applied to juvenile justice. NPC Research in Oregon, USA has developed an assessment tool based on this strengths perspective for juvenile justice (Mackin et al. 2005). Kurtz and Linnemann (2006) have stated strength-based case management techniques used an evaluation of an innovative probation program which produced promising results in terms of reducing recidivism. The strength-based practices elements have been used in juvenile reentry initiative by The Boys \& Girls Clubs of America.

According to Hamilton, Hamilton and Pittman (2004), among positive youth development principles that need to be acquired are from the aspects of positive attitude improvement, social interaction, academic achievement improvement and skills development. All these 
principles, which are based on strengths perspective, need to be identified by each client. Thus, this perspective is seen as a compatible guide in the research of juvenile rehabilitation program.

\section{How Positive Youth Development is viewed as an Effective Indicator of Juvenile Rehabilitation Program?}

The effectiveness of juvenile rehabilitation program can be viewed from the aspect of positive youth development. One of the elements is from the aspect of their negative behaviors that change towards positive behaviors. This is in accordance to the positive youth development principle where individual asset such as individual inner strengths that are important to be developed. These internal strengths consist of cognitive strength, emotion and behavior that construct the internal aspect to become better (Lerner et al., 2005).

The effectiveness of rehabilitation program that uses positive youth development principle also is viewed from the aspect of ecological asset development. Ecological asset development is an external asset such as social network, institutional network, surrounding individual and the ability to access various sources (Lerner et al., 2005). Good relationship between executors and trainees has to be established to acquire a positive effect on the trainees (Hayati, 2015). Rehabilitation program that can encourage positive interaction between the trainees and executors, and between trainees and their peers, and provide opportunity for them to develop bond with the society has shown its effectiveness on positive youth development (Barton \& Butts 2008). This aspect of ecological asset development can also be achieved through physical activities (Eccles \& Gootman, 2002). Trainees are encouraged to be active in co-curricular and sports activities so they can interact among them and to nurture pro-social behavior among them (Eccles \& Gootman, 2002). The participation in physical activity can also uplift self-esteem among juvenile trainees (Bruyere, 2002).

In addition, reform program's effectiveness is also seen from the aspect of positive youth development based on trainees' education improvement (Barton \& Butts, 2008; Eccles \& Gootman, 2002). There are various rehabilitation centers overseas such as in Europe, America and Australia that emphasize on positive youth development from the aspect of education especially academic and vocational skill aspects. According to Gedhof et al., (2015), positive development such as education and skills improvements can be implemented through program that builds skills set that includes social skills and critical thinking, encourages their ability to practice the skills and enhances access on related contextual source. Furthermore, in the context of rehabilitation program, the effectiveness of the program can be attained by empowering the trainees through education exposure. This is to ensure the trainees can obtain employment opportunity after their release from the reform centre (Steuree et al., 2001). A study by Steuree et al., (2001) has found that the trainees that were given education while they were at the reform centre have obtained work with a higher income after the release from reform centre. Visher, Dubus and Yahner (2008) have stated that 21 percent of the released trainees have acquired work that is appropriate with the skills learned at the centre. The findings of the results show that education empowerment can has a positive impact on the trainees.

\section{Conclusion}


This article discusses on how positive youth development can be used as an indicator for the effectiveness of juvenile rehabilitation program. Positive youth development includes cognitive development, virtues inculcation, positive social interaction, self-skills development and education improvement among juvenile trainees. Achievement level of positive youth development demonstrates the extent of effectiveness of a rehabilitation program's execution. Thus, to ensure the effectiveness of this rehabilitation program to the juvenile trainees, the indicator of positive youth development needs to be emphasized by the administrators and executors of the rehabilitation program. This literature review is hoped to be beneficial to future researchers, social workers, administrators and executors of rehabilitation program.

\section{Acknowledgement}

The author would like to express sincerest gratitude and thanks to University Sultan Zainal Abidin (UniSZA) and Ministry of Higher Education Scholarship (SLAB) for supporting this study.

\section{Corresponding Author}

Hezzrin Mohd Pauzi,

School of Social Work, Faculty of Applied Social Sciences, University Sultan Zainal Abidin, Gong Badak Campus, 21300 Kuala Terengganu, Terengganu, Malaysia.

Email: hezzrinpauzi@unisza.edu.my

\section{References}

Barton, W.H. \& Butts, J.A. (2008). Building on Strength: Positive Youth Development in Juvenile Justice Programs. Chicago: Chaplin Hall Center for Children.

Brett L. Bruyere. 2002. Appropriate Benefits for Outdoor Programs Targeting Juvenile Male Offenders. Journal of Experiential Education, 25(1), 207-213.

Cunneen, C. \& Luke, G. (2007). Recidivism and the Effectiveness of Criminal Justice Intervention: Juvenile Offenders and Post Release Support. Current Issues in Criminal Justice, 19, (197).

Eccles, J., \& Gootman, J. A. (Eds.) (2002). Community Programs to Promote Youth Development. Board on Children, Youth, and Families, Division of Behavioral and Social Sciences and Education, National Research Council and Institute of Medicine. Washington, DC: National Academy Press.

Geldholf, G. J., Bowers, E. P., Mueller, M. K., Napolitano, C. M., Callina, C. S., Walsh, K. J., Lerner, J. V., \& Lerner, R. M. 2015. The five Cs model of positive youth development. In E. P. Bowers, G. J. Geldhof, S. K. Johnson, L. J. Hillard, R. M.

Hershberg, J. V. Lerner, \& R. M. Lerner. Promoting positive youth development: Lessons from the 4-H study. New York, NY: Springer.

Hamilton, S. F., Hamilton, M. A., \& Pittman, K. (2004). Principles for Youth Development. In Hamilton, S.F \& Hamilton, M.A. The Youth Development Handbook: Coming of Age in American Communities. Thousand Oaks, CA: Sage Publications.

Kurtz, D., \& Linnemann, T. (2006). Improving probation through client strengths: Evaluating strength based treatments for at-risk youth. Western Criminology Review, 7(1), 9-19.

Lerner, R. M., Lerner, J. V., Almerigi, J., Theokas, C., Phelps, E., Gestsdottir, S., Naudeau, S., Jelicic, H., Alberts, A. E., Ma, L., Smith, L. M., Bobek, D. L., Richman-Raphael, D., Simpson, I., Christiansen, E. D., \& Eye, V. A. (2005). Positive youth development, 
participation in community youth development programs, and community contributions of fifth grade adolescents: Findings from the first wave of the 4-H study of positive youth development. Journal of Early Adolescence, 25(1), 17-71.

Lerner, R. M., Napolitano, C. M., Boyd, M. J., Mueller, M. K., \& Callina, K. S. (2013). Mentoring and positive youth development. In D. L. DuBois, \& M. J. Karcher. The handbook of youth mentoring. Thousand Oaks: Sage Publications Inc.

Mackin, J. R., Weller, J. M, Tarte, J. M., \& Nissen, L. B. (2005). Breaking new ground in juvenile justice settings: Assessing for competencies in juvenile offenders. Juvenile and Family Court Journal, 23 (2), 25-37.

Overton, W. F., \& Muller, U. (2012). Meta-theories, theories and concepts in the study of development. In R. M. Lerner, M. A. Easterbrooks, \& J. Mistry. Comprehensive handbook of psychology: Developmental psychology. New York: Wiley.

Ahmad, P. H. M. (2015). Kaunseling Motivasi Dalam Penyalahgunaan Dadah. Kuala Lumpur: Dewan Bahasa dan Pustaka.

Saleebey, D. (2006). The Strengths Perspective in Social Work Practice. Boston: Pearson Education Allyn and Bacon.

Saleebey, D. (1992). The Strengths Perspective in Social Work Practice: Power in the People. White Plains, NY: Longman.

Spiranovic, C., Cockburn, H., Bartels, L. \& Julian, R. (2015). Outcome Measures for Evaluating the Effectiveness of Juvenile Justice Programs. Victoria University Law and Justice Journal, 5(1), 23-33.

Steurer, S. J., Smith, L., \& Tracy, L. (2001). OCE/CEA three state recidivism study. Retrieved from http://www.ceanational.org/documents/3StateFinal.pdf.

Visher, C., Dubus, S., \& Yahner, J. (2008). Employment After Prison: A Longitudinal Study of Releases in Three States. Washington, D. C.: The Urban Institute Justice Policy Cente 